\title{
RESEÑAS
}




\section{HISTORIA DE UNA REFORMA EDUCATIVA SOCIALISTA}

Recientemente se editó con el aporte financiero de la Cooperativa de la Universidad Pedagógica Nacional la Obra "Historia de una Reforma Educativa Socialista", del Catedrático Jorge Mora Forero. Con excelente prólogo del Historiador Javier Ocampo López, el trabajo presentó la reforma educativa que instauró en Méjico el régimen del General Lázaro Cárdenas.

Con una amplia base documental el autor divide el esfuerzo investigativo en tres grandes Capítulos: 1. El Debate que desencadenó la Reforma Constitucional. 2. Lo relacionado con los programas y textos y 3 . La educación socialista en la práctica.

En la primera parte se describen y analizan los candentes debates que se originaron a raíz de la reforma del Artículo Tercero de la Constitución de 1917, sobre manejo y control de la Educación. Esto dio lugar al surgimiento de dos bandos casi irreconciliables. De un lado la Iglesia Católica alineada con los sectores más retar-datarios y por el otro el sector reformista. Es importante destacar aquí, que la historia educativa mejicana y la colombiana tienen demasiados puntos en común. Por la misma época que se debatían las reformas en el país azteca, en el nuestro el primer gobierno de López Pumarejo hacía esfuerzos por sustraer la educación pública de la égida de la Iglesia cuando propuso en 1936 la reforma de los artículos 38 y 41 de la Constitución de 1886 y la posterior reforma educativa. En Colombia como en Méjico, el clero cerró filas con los grupos más conservadores en contraposición a sectores algo progresivas. Es más, se llevó a afirmar que la Constitución del 36 "estaba inspirada en las formas mejicana y soviética". ("El Siglo", febrero 14 de 1936).

Por otra parte, el impulso a la educación popular y a la desacralización educativa postulada por Cárdenas en Méjico y López en Colombia, les representó no pocos anatemas. La oposición a las reformas fue tan radical que la Iglesia en los dos países ordenó a los padres de familia abstenerse de enviar a sus hijos a las escuelas. Pero si los planes reformistas tenían mucha similitud, es indudable que la reforma mejicana fue más decidida, cuando llegó a establecer en los textos constitucionales que la enseñanza que impartiera el Estado sería socialista, con exclusión de toda injerencia del clero en el manejo y orientación del aparato escolar. El primer capítulo del trabajo el profesor Mora constituye pues, un buen material para realizar un análisis comparativa de las Reformas del gobierno de la "Revolución en Marcha" y del régimen Cardenista.

Ahora bien, la parte relativa a los programas y los textos no es menos interesante; aborda además lo relacionado a la formación del magisterio, tema fundamental en cualquier reforma educativa. El aspecto de los textos escolares es acertadamente enfocado. Analiza como una Educación socialista requería unos textos acordes con esa ideología y programados con base en la filosofía de la lucha de clases. Los materiales de enseñanza tuvieron un énfasis tal en la educación popular, que una de las conclusiones del trabajo de Mora sostiene: "Desde el primer año los libros procuraban hacer que el niño proletario se identificará con su padre y, por lo tanto, que buscará la misma profesión: ser obrero. Con mucha frecuencia se utilizaron los versos como método pedagógico y de ideologización" (pág. 111). En lo concerniente a la formulación Normalista hace un preciso y detallado análisis de las reformas curriculares, y explica como se orientaron a apuntalar una escuela basada en los principios marxistas. 
En el tercer Capítulo el autor realiza un pormenorizado análisis de los múltiples obstáculos que entorpecieron la implantación del sistema socialista en la educación mejicana. En primer término, examina como los padres de familia y los maestros estaban profundamente divididos y vastos sectores no apoyaban las nuecas concepciones educativas. Factor que originó radicales pugnas entre partidarios opositores a la reforma, conflictos que son estudiados con buen criterio analítico. En segundo término detalla la virulenta oposición de la Iglesia, que con el aval del Vaticano buscaba obstaculizar por todos los medios la escuela socialista por constituirse en una "fuente de antirreligión y de inmoralidad, lo primero implicaba lo segundo" (pág. 144). En tercer lugar, reseña los diversos antagonismos que se originaron entre los maestros y las autoridades por razones puramente federativas, como los aumentos salariales o la lucha por mejores condiciones de trabajo. Describe finalmente como estos enfrentamientos fueron acicateados por asesinatos y torturas a los maestros más comprometidos en la práctica de la escuela socialista.

Al terminar de leer el libro de Mora, nos queda la sensación de habernos encontrado con una obra polémica y bien documentada, que apunta a un tema tan apasionante como el de la educación y la ideología que le es subyacente. También nos evidencia como la sola institucionalización de la educación socialista, en una sociedad regida con estructuras de libre empresa, no es suficiente para garantizar una educación laica y democrática.

Ahora bien, algunas conclusiones del trabajo parecerán exageradas, pero se puede afirmar sin ambages que es un buen libro.

CESAR A. VERA G. 